\title{
Forensic team digs up Haiti's deadly past
}

Port-au-Prince, Haiti. Elisyen and JeanPierre Dazme were riding pillion on a motor-cycle past an army barracks on the afternoon of 2 October 1991 when, according to friends and family, they were shot in the back by troops involved in a military coup that had taken place two days earlier.

Last week (20 September), their bodies were exhumed from a graveyard at Gonaives, one hundred miles north of Port-au-Prince, by forensic anthropologists who say that they intend to apply their science to finding out the truth about the cousins' deaths.

The exhumations were carried out by a team of forensic experts from Argentina, Guatemala and the United States who came to the troubled island to help a Commission on Truth and Justice, established in March by President Jeanrights abuses. It has been estimated that more than 3,000 people died at the hands of the now-disbanded Haitian army and its allies between the 1991 coup and Aristide's return a year ago, which was backed by the United States.

"The commission will not investigate all of these cases," says its president, Françoise Boucard. "It intends to clarify the nature of the repression, and identify the character of the human rights violations." Where possible, the commission is also mandated to identify the individuals responsible, although it will not handle their prosecution.

The forensic team is using a wide range of techniques, refined during 15 years of extensive investigations in Argentina and elsewhere in Latin America, to establish identity and cause of death from skeletal remains.

Luis Fondebrider, an Argentinian member of the team, works quickly and meticulously on the exposed cadaver of Elisyen Dazme. "This technical part is only a small component of our work," he explains later. Bertrand Aristide, to investigate human

The larger part, he says, is piecing together information on the circumstances of death and the location of bodies from local people.

Most of Dazme's burial clothes have rotted away. But the synthetic fabric of his tie and socks survive, the latter containing a full collection of foot bones that will later be

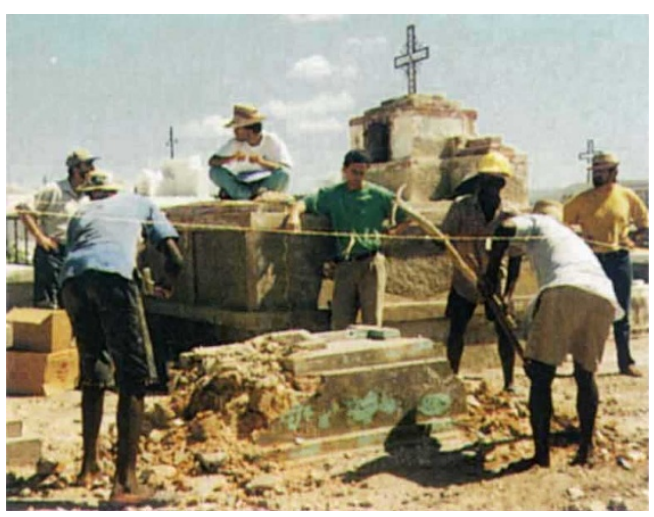

Body of evidence: the exhumation of remains begins examined at an improvised laboratory at a hospital in Port-au-Prince.

Family and friends look on, sombre but calm, even as the exhumation is accompanied by the ritualized shrieking and wailing of another funeral nearby. They say that they hope the exercise will lead to justice, and are encouraged in this view by Father Daniel Roussière, a French Roman Catholic priest and human rights activist, who stayed with the people of Gonaives through the dark days of the repression.

He says that this exhumation, as well as several others recently carried out, will "prove that there was a massacre of the civilian population" after a demonstration against the coup in Gonaives on 2 October 1991 in which seven people were killed and 80 injured. Roussière names an army colonel, now in exile in the United States, as being responsible. Other officers involved

\section{Funding squeeze for German universities}

Munich. Germany's Länder governments agreed last week to back a controversial financing plan proposed by the federal government for Germany's university building programme. This limits spending to DM3.6 billion (US\$2.5 billion) in 1996 rather than the DM4.6 billion that had been earlier recommended by the Wissenschaftsrat, the national science council, as the minimum necessary to meet current demands on higher education.

As a result of the decision, no new buildings will be started next year, and only two-thirds of the research equipment costs recommended for support by the Wissenschaftsrat will in fact be funded (see Nature 373, 95; 1995).
The Länder, which share the cost of the building programme with the federal education and research ministry, rejected an offer from the minister, Jürgen Rüttgers, to add a further DM80 million to the federal government's share in exchange for their support for an additional cost-saving proposal, namely to charge students interest on loans (see Nature 376, 105; 1995).

Instead, both sides agreed to set up a working party to investigate new models of financing the building programme. In particular they will study a proposed leasing plan, under which private investors will cover the initial cost of building, to be paid back by universities through long-term leases on the buildings. are already being prosecuted in Haiti.

Roussière says that the exhumation found broken bones, indicating that Dazme had been shot. But the scientists were not able to confirm this before the formal examination of the bones at the hospital. The examination will be carried out by Karen Burns of the University of Georgia, a pioneer of forensic anthropology who trained other team members on previous missions. She points out that fatal bullets to the body do not necessarily fracture bones, thus leaving no firm evidence of the cause of death.

Information from the exhumations will be made public in the report of the Truth Commission, due by December, with information compiled on a computer database from 5,000 complaints of human rights abuses filed so far by people all over Haiti.

But the report is unlikely to contain much forensic information about 'killing fields' or mass graves that some islanders have alleged exist at two Port-au-Prince sites. One, at Titanyen, is a sprawling area of volcanic ash where bodies of the destitute are dumped, unburied; scientists consider it impractical to identify the victims of summary executions among the scavenged remains.

Furthermore, at Fort Dimanche, the city's recently disused prison where the children of newly arrived squatters play amidst the garbage and mosquito-plagued pools of human waste, there are also said to be too many bodies, buried over too many years.

Indeed, according to Jose Pablo Baraybar, a forensic investigator working for the United Nations (UN) civilian mission to Haiti, 'killing fields' as such may not exist in Haiti. The pattern of executions was sporadic, he says, with bodies often left lying in the streets, like those of the Dazme cousins. The exhumations, he hopes, will provide "a missing link between the testimonies of relatives and other kinds of evidence".

Officials of the UN, which is providing some technical support for the Truth Commission but does not itself have a mandate to investigate pre-1993 human rights violations, privately express reservations about the public conduct of the exhumations. Doubts about Aristide's commitment to justice, as opposed to retribution, may also explain the difficulty the commission has had in raising funds from abroad.

But Dan Salcedo of the human rights programme at the American Association for the Advancement of Science, sponsor of the international forensic team, believes that the mission "is working out well", and will help to build democracy and justice in Haiti.

"As fragile as the judicial system is, it is improving, and technical help will be invaluable to that process" he says. "Until you have physical evidence, there are always people that will say that [abuses] just didn't happen."

Colin Macilwain 